Zaholotnii 5., Mogilei 5.

\title{
OPTIMIZATION OF THE METHOD OF CONSTRUCTING REFERENCE PLANS OF MULTIMODAL TRANSPORT PROBLEM
}

Класична транспортна задача полягає у визначенні оптимального плану перевезень вантажів з пунктів відправки до пунктів доставки за критерієм мінімальної собівартості таких перевезень. Така задача враховує лише один вид транспорту, що в недостатній мірі відповідає практичним потребам сучасних логістичних підприємств. Саме тому об'єктом даного дослідження є класична транспортна задача, постановка якої враховує наявність кількох засобів доставки вантажу, а саме: автомобільного, залізничного та водного. Транспортну задачу такого типу визначено як мультимодальну.

Реалізачія мультимодальної транспортної задачі передбачає використання різноманітних чисельних методів та виконується за допомогою програмних засобів. Фактично, конщептуальний підхід до їі розв'язання полягає в простому підборі можливих розв'язків. За умови великої розмірності задачі такий підхід може бути надзвичайно громіздким, а тому потребує певного удосконалення.

Під час проведення дослідження було оптимізовано метод побудови опорного плану такої задачі на основі критерію мінімізації кількості чисельних ітерачій, обгрунтовано переваги запропонованого підходу у порівнянні з уже відомими. В основу нового підходу було покладено раніше відомий метод мінімального елемента, що використовується при розв'язанні транспортної задачі, а також проведено аналогію із задачею Штейнера. Останнє, в свою чергу, дало змогу означити новий підхід як метод Штейнера.

Результатом дослідження є розробка загального алгоритму реалізацї запропонованого методу Штейнера. В якості апробачї даного алгоритму подано модельний приклад, який демонструє ідентичність результатів розв'язання мультимодальної транспортної задачі всіма розглянутими в роботі способами.

Розробка нових методів реалізащї мультимодальної транспортної задачі дозволить побудувати ефективні алгоритми розв'язання більш комплексних задач транспортної логістики. Критерій зменшення кількості чисельних ітерацій, застосований на всіх етапах реалізацї таких задач, значно скоротить час відшукання їхніх розв'язків.

Ключові слова: мультимодальна транспортна задача, опорний план, критерій оптимізачї, бізнес-модель.

\section{Introduction}

In the context of globalization of the world economy, the issue of transport interaction between buyers and suppliers of various goods, which sometimes can be located at different ends of the planet, becomes ever more acute. In these conditions, the study of optimal cargo delivery strategies is of particular relevance.

The practice of transport logistics poses new challenges for such branches of science as mathematical programming, operations research, optimization theory, and others. Solving such problems requires the use of integrated approaches based on a combination of various research methods inherent in related scientific fields. Of particular importance is the question of the optimality of such approaches. Thus, the relevance of this research is fully justified due to the presence of a sharp applied need for finding the optimal algorithms for solving modern problems of transport logistics.

\section{The object of research and its technological audit}

The object of research is a classical transport problem, the formulation of which provides for the presence of several means of cargo delivery, namely: road, rail and water.
This type of problems refers to those that are cumbersome enough for manual implementation. In other words, to solve this problem it is necessary to use software tools applications or mathematical packages. From the point of view of the mathematical apparatus for the implementation of such problems, it is necessary to use various numerical methods.

In the presence of a small number of points of departure and delivery of goods, this transport task will be of small dimension. However, in practice, the number of such points may amount to tens or even hundreds. This indicates potential problems with finding a solution to a problem. In particular, the question arises of the qualitative convergence of the indicated numerical methods, which, however, may adversely affect the accuracy of the calculations.

This implies the need to prevent a situation in which transport tasks that will be realized in practice give inaccurate or unsatisfactory results. Thus, it is worthwhile to focus on detailing the existing algorithms for the implementation of transport tasks with several means of cargo delivery, as well as on their optimization and improvement. It is proposed to begin primarily with the construction of the support plans of the problem - in the future this approach can be extended to other stages of its solution. 


\section{The aim and objectives of research}

The aim of research is investigation of existing and proposition of more advanced methods for constructing support plans for a transportation task with several means of cargo delivery based on the criterion of reducing the number of multiple iterations when finding its solutions.

Achieving this goal involves the following tasks:

1. To carry out the general formulation of the transportation problem, which provides for the presence of several means of cargo delivery, formalizing the objective function (criterion) of optimization and an admissible set of solutions.

2. To develop in a general form a new improved algorithm for solving the problem and adapt it.

\section{Research of existing solutions of the problem}

Referring to the term «multimodal transport problem», it is worth considering the results of the research given in [1]. In this source, the authors point out certain differences between multimodal and intermodal transportation. The main one of these differences is the regulation of multimodal transportation by the terms of a single contract, which, on the contrary, is not the case for intermodal transportation.

It is proposed to discard the legal aspect of the problem as insignificant for this study, and consider the multimodal transport task such that it is a classical transport task with several means of cargo delivery (transportation by all types of transport is carried out «in parallel», without transshipment points). On the other hand, the intermodal transport task, although it will take into account several means of cargo delivery, however, will provide for the implementation of transportation by «sequentially» various types of transport and through transshipment points.

A task that combines the features of multimodal and intermodal transport problems will be called a mixed (combined) transport problem. It is worth noting that in practice the most frequently encountered transport systems (and, consequently, tasks) are of mixed type.

On the other hand, in [2], the authors among the components of the multimodal transport system distinguish customs clearance of goods and export-import operations. The model of a multimodal transport problem does not perceive these components as essential, since they do not particularly affect its mathematical interpretation. Moreover, it suffices to consider a multimodal transport problem, which is implemented within one country and by one logistic operator. A similar business model using several types of transport is typical, in particular, for Ukrainian enterprises (Nibulon LLC, Mykolaiv, etc.). And although they mainly use multimodal transportation in their activities, this study will focus on their multimodal aspect.

The objectivity of this approach is partially confirmed in [3], where the authors consider the intermodal type of transportation as a special case of multimodal transportation. Indeed, just considering the presence of transshipment points in the formulation of a multimodal transport task and excluding from it all but one of the modes of transport functioning «in parallel», such a task can be reduced to an intermodal one. In the end, in this case, there is no need to introduce the concept of a mixed transport problem.
Regarding the choice of means of delivery of goods, it is also worth paying attention to the business models of Ukrainian and foreign enterprises. Many of them use primarily road, rail and river (inland waterway) modes of transport. Thus, in [4], a comparative characteristic of the main vehicles, in particular, freight logistics, was provided. It is the above-mentioned types of transport in the complex that have such advantages as high speed, low cost level, wide range of goods and the ability to transport large volumes of goods, reliability and ease of transportation.

Continuous improvement of the logistics of freight traffic entails the optimization of economic and mathematical models of these schemes and methods for their implementation. In this context, the criterion for minimizing the cost of transportation remains unchanged, but at the same time, all new optimization criteria (objective functions) are added. In [5], in addition to the criterion of the minimum cost, the author proposes to minimize the time of transportation of cargo. As significant parameters, it is proposed to adopt the operational speed and net payload of vehicles. Further, the cost function is minimized in the framework of the corresponding model, the implementation algorithm of which consists of two stages:

1. With the help of geometric programming methods are the values of the parameters of the vehicle, minimizing the objective function.

2. With the help of one of the well-known methods for solving a classical transportation problem, a transportation plan is found that minimizes the objective function.

On the other hand, the multimodal transport task may not contain the objective function of minimizing the time of transportation, however, be dependent on a time variable. Such a problem attracted the attention of researchers in [6]. To solve this problem, a model of transfer graph is proposed - the authors of the work note that in the process of practical computer implementation of this model, a balance was reached between the computation time and the use of computer memory resources. In general, this aspect indicates the importance of maintaining this balance in the implementation of all types of multimodal transport tasks.

The same authors continue this thought in [7]. In this paper, a parallel algorithm is proposed for solving a timedependent multimodal transportation problem for very large transportation networks. Again, the researchers pay special attention to the use of sufficiently powerful computer software in the implementation of this algorithm.

In any case, such a formulation of the problem is only one possible. Returning to the classic single-criteria (at minimum cost) transport problem, it is worth considering the possibility of taking into account several means of cargo delivery in it.

A special place in this context is occupied by the socalled distribution transport problem. It, in contrast to the classical transportation problem, takes into account the presence of several types of transport, however, it suggests that all goods are delivered only to one train. However, even in this case, the algorithm for solving such a distribution task is significantly complicated and requires implementation with the help of specialized software.

In the context of the choice of such software, one should indicate a variety of packages and applications, the functionality of which allows one to realize a multimodal transport task. An example of such software is TIMIPLAN - a special application developed during the 
implementation of the automation project of a Spanish logistics company and designed to handle about 300 shipments daily [8]. But, within the framework of this study, MS Excel functionality will be quite enough.

The importance of conducting research in this direction for logistics operators is discussed, in particular, in [9]. On the example of the Republic of Slovenia, the authors of this work consider the processes of integration of the transport system of this country into the European transport infrastructure. They point to an increase in the efficiency of the logistics operators, primarily in the process of implementing multimodal transport operations, and offer their own model of a mixed logistics operator.

Moreover, the efficiency of logistic operators is growing in the context of creating so-called transport hubs or, in other words, large multimodal transport hubs. The functioning of just such formations is considered by the authors in [10], using the methods of micro-stimulation in the research process. It is also worth noting that in this paper the interdependencies between such types of transport as road, water and rail are studied.

Returning to the methods of implementing multimodal transport problems, it is possible to refer to the experience of combining linear programming approaches and automated planning of transportation processes. This approach is proposed by the authors in [11]. At the same time, the researchers indicate that they use this method of solution for the intermodal transport problem - unlike most previous works in this direction, in which the problem statement did not take into account the presence of several types of transport. Thus, this method can be useful when implementing a multimodal transport problem.

So, the necessity of setting such a multimodal transport problem, which is distinguished from the classical one only by the presence of several means of cargo delivery, is fully justified. The criterion for minimizing the total cost of transportation remains unchanged with the possibility of converting the task to a multicriterial one.

\section{Methods of research}

One of the most common methods for the implementation of the classical transport problem is the method of the minimum element provides for the construction of reference plans, based on the search for the extreme values of the elements from the table of cargo transportation. Let's note that usually the extreme is the minimum value of the elements of the table - according to the criterion of minimizing the objective function of the cost of transportation.

When solving a multimodal transport problem, a modified minimum element method will be proposed, which will provide a reference plan based on a search for the minimum values of the elements of the corresponding cells in the transportation table recorded for each type of transport separately.

Also, according to the method of analogy, this support plan to be considered reproduces a certain «compromise» solution of the problem. This plan will serve as an analogue of the Torricelli point [12] in the well-known Steiner problem [13] - that is, it will be a compromise with respect to the support plans of the multimodal transportation problem, built separately for each type of transport.

The accuracy of the obtained solutions will be verified by the method of comparison - the results of building a compromise reference plan for a multimodal transport problem using each of the approaches described in this study should be the same.

\section{Research results}

6.1. General problem statement. The task is finding the optimal transport plan in the presence of several types of transport: road, rail and water. The optimization criterion for this transportation task is the smallest total cost of transportation.

The mathematical formalization of this problem is as follows:

$$
S=\sum_{i, j=1}^{m, n} a_{i j} x_{i j}+\sum_{i, j=1}^{m, n} b_{i j} y_{i j}+\sum_{i, j=1}^{m, n} c_{i j} z_{i j} \rightarrow \min ,
$$

where $i=\overline{1, n}, j=\overline{1, m}-n$ points of departure and $\mathrm{m}$ points of delivery, respectively; $x_{i j}, y_{i j}, z_{i j}$ - the number of units of goods transported from the $i$-th point of departure to the $j$-th delivery point, respectively, by road, rail and water transport (required values); $a_{i j}, b_{i j}, c_{i j}$ - the cost of transporting a unit of goods from the $i$-th point of departure to the $j$-th point of delivery, respectively, by road, rail and water transport; $S$ - a cost function.

In the general case, this task is closed, since an open problem can be reduced to it, it will not significantly affect the algorithm for solving it. In other words, the sum of the needs of the delivery points is equal to the sum of the stocks at the points of departure. Also, let's restrict ourselves to the consideration of the minimization problem, despite the fact that it is dual to the maximization problem.

Thus, the set of $D$ constraints for problem consists of the following equations and inequalities:

$$
D:\left\{\begin{array}{l}
\sum_{i, j=1}^{m, n} x_{i j} \leq x ; \sum_{i, j=1}^{m, n} y_{i j} \leq y ; \sum_{i, j=1}^{m, n} z_{i j} \leq z ; \\
N_{j}=x_{i j}+y_{i j}+z_{i j}=M_{i},
\end{array}\right.
$$

where $x, y, z$ - the total capacity of the parks of the road, railway and water transport, respectively; $M_{i}, N_{j}-$ the value of stocks in the $i$-th shipping point and the needs of the $j$-th delivery point, respectively.

It should be immediately noted that the first condition of the system (2) indicates the limited parks of each type of transport; however, it will not be taken into account in this study.

Since the tasks of the available means of delivery of goods, the number of which is more than 1, then, accordingly, the solution of the problem is not just one transport plan, but some combination of such plans for each type of transport separately. Therefore, it is necessary to proceed to the method of constructing such combinations.

6.2. Development of the algorithm for the problem implementation. The algorithm for solving the classical transport problem in the presence of a single mode of transport is known. Thus, it is possible to build reference plans for the problem (1), (2), alternately discarding all modes of transport, except one. That is, it is possible to get the optimal solution for road, rail and water transport separately.

So, there is a «compromise» support plan, which should ensure the minimization of the objective function (1). The principle of constructing such a compromise plan 
is similar to finding the Torricelli point in the Steiner problem - that is, a point whose sum of distances from which to the vertices of a triangle is minimal [12].

Further, the Steiner problem can be extended to an arbitrary n-gon [13], or, in the formulation of this problem, to a finite number of means of cargo delivery. Thus, the approach to finding such a compromise plan will be called the Steiner method.

Let's introduce the following notation:

- the cost matrix of transportation by road, rail and water transport, respectively:

$A=\left(a_{i j}\right), B=\left(b_{i j}\right), C=\left(c_{i j}\right)$;

- matrices of road, rail and water transport plans, respectively:

$X=\left(x_{i j}\right), Y=\left(y_{i j}\right), Z=\left(z_{i j}\right)$.

Let's denote the matrix of the compromise transportation plan as $T=\left(t_{i j}\right)$.

Let's introduce the relationship of the product of cost matrixes and transportation plans (for example, road transport):

$$
A \times X=\left(a_{i j}\right) \times\left(x_{i j}\right)=\sum_{i, j=1}^{m, n} a_{i j} x_{i j} .
$$

Thus, taking into account (3), the objective function (1) takes the form:

$$
S=A \times X+B \times Y+C \times Z \rightarrow \min .
$$

To construct the general algorithm of the Steiner method, let's use an approach similar to the minimal element method used in solving the classical transport problem. All elements of the cost of transportation matrix are ranked in ascending order, and the distribution of goods delivered from dispatch points to delivery points begins with the smallest element of this matrix.

So, for a finite number of cargo delivery vehicles, the Steiner method algorithm will be as follows:

1. Build the Steiner matrix, that is, the matrix which elements are the minimum (by the optimization criterion) cost of transportation of each type of transport from the $i$-th point of departure to the $j$-th delivery point:

$$
S t=\left(s t_{i j}\right)=\left(\min \left(a_{i j} ; b_{i j} ; c_{i j}\right)\right) .
$$

That is, the minimum value of the cost of transport is calculated as follows:

$$
S_{\min }=S t \times T \text {. }
$$

2. Write the target cost minimization function - the sum of the products of $S t$ matrix elements and the values of the corresponding indicators of the reference trade-off plan of transportation:

$$
S=S t \times T^{*} \rightarrow \min ,
$$

where $T^{*}$ - the matrix of the reference (non-optimal) compromise transportation plan.

3. Minimize the objective function $S$ - obtain the minimum value of the cost of transportation (6) and the opti- mal compromise transport plan - that is, the condition is satisfied.

4. Generate a multitude of combinations of reference plans for each type of transport, among which we select the optimal one (an example of such generation is given below).

6.3. Adaptation of the developed algorithm using the model example. For the efficiency of demonstration of the application of methods for implementing the task, let's use a model example. In this example, assume that there are three shipping points and three shipping points. Let's solve the problem using MS Excel in the following two ways:

1 way. Minimize the cell containing the objective function. Let the cost of transport for each mode of transport is as follows (Tables 1-3).

Table 1

Cost of road transport

\begin{tabular}{|c|c|c|c|}
\hline Road & $b 1$ & $b 2$ & $b 3$ \\
\hline$a 1$ & 5 & 4 & 9 \\
\hline$a 2$ & 3 & 1 & 7 \\
\hline$a 3$ & 4 & 3 & 1 \\
\hline
\end{tabular}

Table 2

Cost of rail transportation

\begin{tabular}{|c|c|c|c|}
\hline Rail & $b 1$ & $b 2$ & $b 3$ \\
\hline$a 1$ & 10 & 8 & 8 \\
\hline$a 2$ & 8 & 11 & 7 \\
\hline$a 3$ & 4 & 3 & 1 \\
\hline
\end{tabular}

Table 3

Cost of river transportation

\begin{tabular}{|c|c|c|c|}
\hline Biver & $b 1$ & $b 2$ & $b 3$ \\
\hline$a 1$ & 6 & 2 & 8 \\
\hline$a 2$ & 2 & 3 & 6 \\
\hline$a 3$ & 5 & 2 & 9 \\
\hline
\end{tabular}

The needs of delivery points are $120,80,100$, respectively. Stocks at the dispatch points are 150, 90,60, respectively. The first supporting plans for each mode of transport are separately taken as zero. The objective function of the task - the sum of the products of the cost of transportation for their volume - is given in the form (1) or (4). Further, with the help of the add-on «Search for a solution let's minimize this objective function. Let's receive transportation plans, are given in Tables $4-6$.

Table 4

Optimal road transport plan

\begin{tabular}{|c|c|c|c|}
\hline Road & $b 1$ & $b 2$ & $b 3$ \\
\hline$a 1$ & 30 & 0 & 0 \\
\hline$a 2$ & 0 & 0 & 0 \\
\hline$a 3$ & 0 & 0 & 60 \\
\hline
\end{tabular}


Table 5

Optimal rail transport plan

\begin{tabular}{|c|c|c|c|}
\hline Rail & $b 1$ & $b 2$ & $b 3$ \\
\hline$a 1$ & 0 & 0 & 21 \\
\hline$a 2$ & 0 & 0 & 0 \\
\hline$a 3$ & 0 & 0 & 0 \\
\hline
\end{tabular}

Table 6

Optimal river transport plan

\begin{tabular}{|c|c|c|c|}
\hline River & $b 1$ & $b 2$ & $b 3$ \\
\hline$a 1$ & 0 & 80 & 19 \\
\hline$a 2$ & 90 & 0 & 0 \\
\hline$a 3$ & 0 & 0 & 0 \\
\hline
\end{tabular}

The optimal value of the objective function in this case will be equal to 870 .

It is easy to make sure that the total compromise transport plan (the sum of the values of the corresponding cells of each individual plan) will be as follows (Table 7).

Table 7

The total compromise transportation plan

\begin{tabular}{|c|c|c|c|}
\hline All types of transport & $b 1$ & $b 2$ & $b 3$ \\
\hline$a 1$ & 30 & 80 & 40 \\
\hline$a 2$ & 90 & 0 & 0 \\
\hline$a 3$ & 0 & 0 & 60 \\
\hline
\end{tabular}

At the first stage it is necessary to find a compromise transport plan. For this, let's build the Steiner matrix $S t$ in the form (5).

$$
S t=\left(\begin{array}{ccc}
\min (5 ; 10 ; 6) & \min (4 ; 9 ; 2) & \min (9 ; 8 ; 8) \\
\min (3 ; 8 ; 2) & \min (1 ; 11 ; 3) & \min (7 ; 7 ; 6) \\
\min (4 ; 1 ; 5) & \min (3 ; 1 ; 2) & \min (1 ; 12 ; 9)
\end{array}\right)=\left(\begin{array}{ccc}
5 & 2 & 8 \\
2 & 1 & 6 \\
1 & 1 & 1
\end{array}\right)
$$

Let's multiply this cost matrix by a basic trade-off transportation plan. Next, minimize, according to (6), (7), the corresponding cell in MS Excel. Let's obtain a result similar to that obtained using the first method, the minimum cost of transportation $S_{\min }=870$, and the following compromise transportation plan $T$ (Table 8).

Table 8

Compromise transport plan

\begin{tabular}{|c|c|c|c|}
\hline All types of transport & $b 1$ & $b 2$ & $b 3$ \\
\hline$a 1$ & 30 & 80 & 40 \\
\hline$a 2$ & 90 & 0 & 0 \\
\hline$a 3$ & 0 & 0 & 60 \\
\hline
\end{tabular}

Next, it is necessary to generate many combinations of transportation plans for each of the modes of transport. So, if the amount of traffic from point to point is 30 , then it is necessary to take all the options for obtaining such a result by adding three (by the number of types of transport) components, for example, $30+0+0,29+1+0$, and so on. The approach will generate a fairly voluminous array of combinations of plans, among which it will be necessary to choose the optimal one. Obviously, it will be a rather cumbersome task to do this manually, so here it is worth referring again to the application software.

Based on the assumption that the number of modes of transport is equal to three (for example, road, rail, and water), the task dimension $3 \times 3$ is implemented in MS Excel. To solve the problem, two methods were applied: minimization of the cell containing the objective function and the Steiner method.

The use of the Steiner method accelerates the process of finding the optimal plans for the transportation problem, the condition for which is the presence of several types of transport. A hypothetical reduction in the number of iterations in the process of implementing such a task can significantly optimize the operation of the software in cases when it is necessary to find a solution to the dimension problem at $m \times n$ at $m, n \rightarrow \infty$.

\section{SWOT analysis of research results}

Strengths. The developed method for building support plans for a multimodal transport task begins a qualitatively new approach to the implementation of tasks of this type. In fact, being a way of detailing the algorithm for constructing support plans, the Steiner method is a weighty step towards reducing the number of numerous iterations in solving the transportation problem, the formulation of which involves several methods of cargo delivery.

Weaknesses. Clarifying and detailing with the aim of reducing the number of numerous iterations, the methods of solving the multimodal transport problem are already known; the Steiner method itself expands and complicates the general algorithm for constructing the support plans for such a task.

Opportunities. The Steiner method can be extended to more complex business models - that is, to broader classes of multimodal or mixed transport problems. In addition, the application of the approaches laid down in it at all stages of the implementation of a transport task can be quite effective in terms of optimizing the process of solving it.

Threats. The complexity of the developed Steiner method can potentially offset the benefits of reducing the number of multiple iterations, adding cumbersomeness to the process of constructing support plans for a multimodal transportation problem.

Optimization of the existing methods for implementing the multimodal transport problem potentially allows a significant reduction in the number of numerous iterations in the construction of its support plans, however, it inevitably leads to the complication of the general algorithm for solving this problem. However, this complication will be fully justified, in particular, in the implementation of transport tasks that form the basis of more complex business models.

\section{Conclusions}

1. In this paper, a study of existing methods for constructing support plans for the transportation problem with several means of cargo delivery is conducted, and the task itself is defined as multimodal. On the basis of the criterion of reducing the number of numerous iterations in finding solutions to such a problem, a more perfect 
method of constructing its support plans, the so-called Steiner method, is proposed. And also a general formulation of the multimodal transport problem is implemented its objective function (criterion) of optimization and an admissible set of solutions are formalized.

2. In general, a new, more advanced algorithm for solving the problem and carrying out its adaptation on a model example is developed. Studying the type of obtained solutions and comparing them with the results obtained using previously known methods allows to speak about the identity of the solutions obtained in various ways.

Thus, the order of the algorithm for selecting the decoupling of the multi-modal problem, it involves the Steiner method, will significantly speed up the process of solving it by reducing the number of multiple iterations.

\section{References}

1. Pasichnyk V. I., Hrysiuk Yu. S., Patsora O. V. Efektyvnist intermodalnykh perevezen yak element zabezpechennia vysokoi yakosti transportnykh posluh // Upravlinnia proektamy, systemnyi analiz i lohistyka. Tekhnichna seriia. 2013. Issue 12. P. 125-131.

2. Shcherbyna R. S. Metodolohichnyi aspekt osnovnykh elementiv zmishanykh perevezen eksportnykh vantazhiv // Zbirnyk naukovykh prats DETUT. Seriia «Transportni systemy ta tekhnolohii». 2015. Issue 26-27. P. 242-249.

3. Lin C.-C., Lin S.-W. Two-stage approach to the intermodal terminal location problem // Computers \& Operations Research. 2016. Vol. 67. P. 113-119. doi: http://doi.org/10.1016/ j.cor.2015.09.009

4. Slavova-Nocheva M. Competitiveness of the transport market in Bulgaria // Ikonomicheski Izsledvania. 2012. Vol. 21, Issue 3

5. Storozhev V. V. Optymizatsiia parametriv transportnykh zasobiv v multymodalnykh systemakh dostavky vantazhiv: Abstract's PhD thesis. Odessa: Odeskyi natsionalnyi morskyi universytet, 2008. 22 p.
6. Solving time-dependent multimodal transport problems using a transfer graph model / Ayed H. et. al. // Computers \& Industrial Engineering. 2011. Vol. 61, Issue 2. P. 391-401. doi: http:// doi.org/10.1016/j.cie.2010.05.018

7. A parallel algorithm for solving time dependent multimodal transport problem: Proceedings / Ayed H. et. al. // IEEE Conference on Intelligent Transportation Systems, ITSC. 2011. P. 722-727. doi: http://doi.org/10.1109/itsc.2011.6082973

8. TIMIPLAN: An Application to Solve Multimodal Transportation Problems / Flórez J. E. et. al. // Scheduling and Planning Applications Workshop (SPARK). 2010.

9. Logistic operator - fundamental factor in rational production of services in multimodal transport / Zelenika R. et. al. // Promet - Traffic - Traffico. 2005. URL: https://trid.trb.org/ view $/ 755378$

10. OPTIHUBS - Multimodal Hub Process Optimization by Means of Micro Simulation / Elias D. et. al. // Transportation Research Procedia. 2016. Vol. 14. P. 457-466. doi: http://doi.org/ 10.1016/j.trpro.2016.05.098

11. Combining linear programming and automated planning to solve intermodal transportation problems / García J. et. al. // European Journal of Operational Research. 2013. Vol. 227, Issue 1. P. 216-226. doi: http://doi.org/10.1016/j.ejor.2012.12.018

12. Zhaldak M. I., Tryus Yu. V. Osnovy teorii i metodiv optymizatsii: textbook. Cherkasy: Brama-Ukraina, 2005. 608 p.

13. Romanovskiy I. V. Zadacha Shteynera na grafakh i dinamicheskoe programmirovanie // Komp'yuternye instrumenty v obrazovanii. 2004. Issue 2. P. $80-86$.

Zabolotnii Serhii, Doctor of Technical Sciences, Professor, Department of Radio Engineering, Telecommunication and Robotics Systems, Cherkasy State Technological University, Ukraine, ORCID: http:// orcid.org/0000-0003-0242-2234,e-mail: s.zabolotnii@chdtu.edu.ua

Mogilei Sergii, Lecturer, Postgraduate Student, Department of Economic Cybernetics, East European University of Economics and Management, Cherkasy, Ukraine, ORCID: http://orcid.org/00000002-9296-6827, e-mail: sergiymogiley@i.ua 